\author{
Textbook: Focus on Students' National Identity
}

\title{
Textbook for IT classes: a fundamental approach
}

\author{
Irina V. Levchenko* (a), Albina R. Sadykova (b), \\ Aleksandr V. Grinshkun (c), Anastasia E. Pavlova (d) \\ (a) Moscow City University, 129226, Moscow (Russia), 4-1, 2nd Selskokhoziastvenny Proezd \\ (b) Moscow City University, 129226, Moscow (Russia), 4-1, 2nd Selskokhoziastvenny Proezd \\ (c) Moscow City University, 129226, Moscow (Russia), 4-1, 2nd Selskokhoziastvenny Proezd \\ (d) Moscow City University, 129226, Moscow (Russia), 4-1, 2nd Selskokhoziastvenny Proezd \\ LevchenkoIV@mgpu.ru
}

\begin{abstract}
The introduction of pre-professional training in the IT field in Russian schools is determined by the development of the digital economy and the information technologies, the need to prepare schoolchildren for professional selfdetermination and to form relevant competencies for future IT specialists. However, there is evidence to suggest the lack of substantive support for in-depth training in the sphere of IT for introducing the pre-professional training in schoolchildren. Therefore, it becomes relevant to form the content of IT training at an in-depth level, which makes it possible to master new skills in this sphere.

The article reveals the problem in determining approaches to forming the content of training programme for IT classes, discloses the possibilities of a fundamental approach to designing the content of a textbook for IT classes.

The analysis of the theoretical sources on pre-professional training in the IT sphere as well as the experience of indepth teaching informatics to schoolchildren made it possible to define the fundamental approach as the basis for designing the plan of the in-depth IT training of schoolchildren.

The results of the study can be the basis for designing the content of fundamental informatics training, which is an invariant component of the pre-professional training of schoolchildren in the sphere of information technologies.

The results obtained will make it possible to design a textbook for IT classes.

Keywords: fundamental approach, in-depth informatics course, IT classes.
\end{abstract}

(C) 2021 Irina V. Levchenko, Albina R. Sadykova, Aleksandr V. Grinshkun, Anastasia E. Pavlova This is an open access article distributed under the terms of the Creative Commons Attribution License (CC BY 4.0), which permits unrestricted use, distribution, and reproduction in any medium, provided the original author and source are credited.

Published by Moscow City University and peer-reviewed under responsibility of TSNI-2021

(Textbook: Focus on Students' National Identity)

\section{Introduction}

* Corresponding author. E-mail: LevchenkoIV@mgpu.ru 
Recent years have been witnessing Russian schools introducing pre-professional training at the level of secondary general education. The demand for such training of schoolchildren in the IT field is determined by socio-economic transformations in our country maintained at the state level (Federal'nyj proekt, 2019; Natsional'naia programma, 2020; Pasport natsional'nogo proekta, 2018; The Presidential Decree, 2018) and is supported by the leading universities, scientific organizations and IT companies of the country.

Pre-professional training at the level of secondary general education is aimed at expanding the practical content of educational programs that, as a rule, imply at least two subjects are studied simultaneously. Another goal is to teach skills relevant for the future profession including IT proficiency as well as for implementing applied projects (Fiziki i liriki, 2017).

Pre-professional training realized during IT classes seeks to advance the practical competencies of schoolchildren, to master skills relevant for the future profession in such areas as programming, IT security, modelling and prototyping, robotics, big data, communication technologies (Kontseptsiya IT-klassy Moskvy, 2019).

Pre-professional training in IT classes involves in-depth training of schoolchildren in the field of informatics which is necessary, taking into account the modern achievements of science and information technologies. The latter allows to form knowledge and skills in informatics to address educational and practical tasks employing modern digital means.

At the same time, practical experience exemplifies the need to determine the methodological foundations for working out the content of an informatics textbook for pre-professional training of schoolchildren in the IT field. Thus, it proves essential to generalize the experience of training informatics at an in-depth level (Kalinin, \& Samylkina, 2019; Semakin, Henner, \& Shestakova, 2020; Polyakov \& Eremin, 2017) to conduct further research. Another issue of primary concern is to work out the in-depth informatics training programme for schoolchildren within the framework of pre-professional education, aimed at mastering the basics of informatics along with brand new information technologies.

All the abovementioned reveals contradiction between the need for pre-professional training of informatics and insufficient content provision of pre-professional training in informatics for schoolchildren. Another issue is the call for an efficient IT classes textbook.

Today sees scientists having turned to the fundamentalization of education, since this direction allows to optimize the educational process and reduce the workload on schoolchildren while mastering the content of 
education. Therefore, the fundamentalization of education proves a necessary condition for its humanization.

Fundamentalization of education makes it possible to support the introduction of personality-oriented learning technologies, information technologies, and pre-professional training of schoolchildren into the education system. Fundamentalization of education makes it possible to raise the level of culture, which is critical while tackling economic and environmental, informational and social problems typical for the modern society. In this regard, one of the ways to improve the education system is due to its fundamentalization.

\section{Purpose and objectives of the study}

The purpose of the study is to determine the issues relevant for schoolchildren's pre-professional training in informatics during IT classes, to define the key approaches to designing the programme of such training, to reveal the possibilities of a fundamental approach enabling to lay out the content of training in informatics as an invariant component of pre-professional training of schoolchildren in the sphere of information technologies, to identify the features of applying the fundamental approach to drafting a textbook for IT classes.

\section{Literature review}

The process of Russian education being modernized is associated not only with humanization, but also with fundamentalization. The latter implies the education directed at creating integral, generalized knowledge, at synthesizing fundamental and technological knowledge, at forming a unified worldview system. Moreover, technological scientific knowledge relies on fundamental knowledge, while fundamental knowledge is focused on technological knowledge (Sadovnikov, 2011). The combination of fundamental and technological knowledge makes it possible to design general models of natural phenomena and social processes (Moskovchenko, 2017).

The fundamentalization of education can be understood as the focus of the educational content on methodologically significant, system-forming knowledge, invariant elements of human culture that contribute to the development and implementation of pupils' creative potential, providing a qualitatively new level of intellectual and moral culture, encouraging an internal need for life-long self-development and self-education, contributing to the adaptation of the individual in a rapidly changing socio-economic and information-technological environment (Grinshkun \& Levchenko, 2011). 
The humanistic paradigm prompts a new meaning for the fundamentalization of education. The latter is bound to seek both fundamentalizing the content of education and humanizing the educational process. Integration of these two aspects allows to improve the system of secondary general education, including pre-professional education (Levchenko, 2009).

The focus of training on comprehending the deep, essential, system-forming foundations and connections between various processes of the surrounding world is a systemic characteristic of the fundamental nature of education (Mel'nik, 2014). Fundamental knowledge retains its value for a long time, it allows you to develop the ability to think, the readiness to independently gain new knowledge.

Accumulating knowledge in different subject areas occurs, as a rule, by "layering" all new particular phenomena and dependencies while maintaining the basis (invariant) as a system-forming component on which all education is built upon (Talyzina, 2018).

It is the approach to selecting the content by clearly identifying the core of the course, its main ideas and leading concepts that determines the principle of generalization of knowledge (Kuznecova \& Testov, 2016). While addressing the concepts, it is necessary to identify their most general, fundamental properties. Therefore, training should begin with the major, general issues dominating the structure. General principles and basic concepts are elements of the structure of any subject under study.

Informatics studies the laws of information processes, the ability to automate information handling, the ways to create general models of information processes. The course of informatics at school is considered as an independent academic subject containing a significant theoretical component, due to which schoolchildren study information technologies and apply them in their practical activities.

The trend towards fundamentalization of the school informatics course is not a unique feature of Russian education. Great Britain is moving in the similar direction. Thus, the school course "Computer science", which is ideologically comparable to the course of informatics taught in Russian schools, is moving towards fundamentalization, standing in a row with the disciplines of mathematics and physics (Moller \& Crick, 2018).

Nevertheless, it is necessary to continue further research to identify the fundamental invariant core of the programme content, the fundamentals determining the advancing improvement of modern IT means.

\section{Methodology}


The authors of the research tended to employ the following research methods: a) a retrospective analysis of the results already obtained by methodologists, identifying the degree of their content richness and logicalscientific correctness, telling the difference of the findings acquired by one author from another one (comparison); b) generalization of ideas presented by methodologists; c) productive synthesis of the ideas put forward by the authors-methodologists with the subsequent adjustment of the precedent results; c) determining "white spots" with realizing the possibilities to fill them up (Korzhuev \& Sadykova, 2018).

The appeal to the philosophical foundations of pedagogy made it possible to identify the "roots" of those ideas, views, approaches, paradigms that function today within the educational space.

In particular, it is the retrospective analysis of scientific-pedagogical literature that is relevant to identify the features of fundamentalizing education to tackle the identified issues. Networking, generalization and systematization of research materials made it possible to identify the need for a fundamental approach to designing the content of informatics training for pre-professional training of schoolchildren in the sphere of information technologies.

The revealed features of the fundamental approach to designing the content allowed to single out the principles of structuring content elements, the further improvement of the informatics course in the frame of the pre-professional training in IT.

The authors claim the identified "white spot" in Russian education is the following: Russian schoolchildren are better than those in many other countries at performing reproductive tasks, however, their results are much worse when addressing non-standard problems, when it is necessary to draw conclusions, forecasts, etc.

The fundamental approach allows to handle the problem identified by focusing on the structural elements of the educational content, on cognitive and creative activities, on the readiness to find non-standard solutions; on implementing emotional-value relationships (Berezhnova \& Kraevskij, 2017).

The highlighted structural elements of the training content characterize the learning process as an activity, which makes it possible to determine the basics of the fundamentalization of education relying on the activity-based approach to learning.

Such features as the integrity and interconnectedness of structural elements indicate a systematic approach to activity and prove basic for the fundamentalization of education. In addition, it was stated that in-depth training in a specific subject area claims it is precisely the fundamental approach to designing the content of 
training in a specific academic subject that is needed.

All this made it possible to transfer the process of designing the content of a textbook for IT classes from the field of pure intuition and conjuncture into a theoretical and methodological field, in which the fundamental criteria for selecting educational material are such parameters and features as the information capacity of a system of knowledge, structuring the system-forming content, humanization of educational material, etc.

\section{Results}

The research resulted in suggesting the fundamental approach to designing the educational content for preprofessional training of schoolchildren in the sphere of information technologies as well as in proposing a fundamental approach to designing the content of a textbook for IT classes.

The research revealed the benefits of the fundamental approach concerning advancing the educational content for the pre-professional training of schoolchildren in the field of information technologies together with determining the theoretical basis for implementing the fundamental approach to designing the content of a textbook for IT classes.

The proposed fundamental approach to designing the educational content for the pre-professional training of schoolchildren in IT classes relies on the current state of the fundamental informatics studies in general, of the educational material to realize the humanitarian component, of training aiming towards the formation of personal fundamental knowledge and skills in schoolchildren in the field of informatics. In our opinion, a fundamental approach to training informatics at the level of secondary general education indicates didactic processing of fundamental foundations for training schoolchildren seeking the system of knowledge and skills acquired by schoolchildren in the field of informatics as well as the knowledge of the world around through the intermediary of methods and means of informatics (e.g. modelling, algorithmization, computer experimenting). It also implies gaining social experience identical to human culture in all its structural completeness with the help of informatics in the process of their pre-professional training in IT sphere.

Further improving the content of informatics training programme being a part of the pre-professional training of schoolchildren attending IT classes is possible due to the fundamental approach to designing the structure of an informatics textbook based on the principles to follow:

- accordance between the subject spheres of informatics as a science and of it being a school discipline; 
- supplementing the content with appropriate training materials and excluding unnecessary material from the content;

- reasonable allocation of variable and invariant parts of the content;

- adapting the content of informatics to the schoolchildren's age group,

- taking into account the previously achieved level of schoolchildren's accomplishment;

- identification and implementation of intersubject and intrasubject connections;

- a balanced combination of fundamental and technological knowledge.

Humanistic paradigm prompts the fundamental approach is due to organizing the content of informatics training meaning the textbook is aimed at forming:

- fundamental and universal knowledge and skills to adapt to rapidly changing information technologies;

- systematic knowledge and skills that allow to see the objects under study interconnected and interacting;

- universal and holistic education for the purpose of understanding the systemic IT picture of the world;

- the willingness to think independently and discover new data, to develop flexible and creative thinking to encourage life-long education;

- skills of interacting in the information environment relevant to live in the information society;

- competencies that allow addressing learning and research tasks.

Requirements for the representation of the system concept in the informatics textbook are defined in accordance with the fundamental approach to designing the content of informatics training:

- concepts essential to be considered within the system;

- concepts should be considered according to their hierarchy;

- the system of concepts is to be full;

- new concepts are addressed relying on the previously mastered ones; 
- concepts are formulated in accordance with the age of the schoolchildren;

- the process of forming the system of concepts should be aimed at teaching, developing and educating schoolchildren;

- concepts are to evolve.

The proposed fundamental approach to structuring the content of pre-professional informatics training to schoolchildren does not contradict the modern tendencies of humanizing Russian education system. It allows to implement personality-oriented learning with a significant activity component.

\section{Discussions}

The results of the research prove basic for upgrading the content of training in fundamental informatics, which is an invariant part of the pre-professional training of schoolchildren in the field of information technologies. When designing the content of a textbook for IT classes, the use of the findings obtained is highly recommended.

The content of informatics course is bound to include facts, theories, models that correspond to modern scientific ideas about the systemic information picture of the world, which are the most fundamental and significant for the formation of a person's information culture, as well as for lifelong education. Due to the high-rocketing technological development some patterns can change specific technical implementations almost beyond recognition in relatively short periods of time. Therefore, it is especially important to design the content of educational material and present illustrative material, minimally depending on specific technical details. The programme should reflect the concepts and didactic elements that make up the invariant part of informatics education.

The sequence of didactic units should be so that first of all the basic concepts, general principles, and fundamental properties are highlighted. This allows to start with the essentials and organize the entire conceptual structure of the content. Concepts determination makes it possible to present training material scientifically, to rethink already known facts, to lay the foundations of the entire system of knowledge, to reveal the internal connections of concepts, to show their manifestations on exact facts and phenomena of the world. In line with modern trends of informatics development, it is necessary to reflect its integrative character, actively apply inter- as well as intradisciplinary connections of informatics training between subjects and within the subject.

The fundamental approach to upgrading the content of informatics should consider humanization processes, 
differentiation and individualization of training, use of personality-oriented learning technologies. The inclusion of basic, supplementary and auxiliary material in the textbook content will create possibilities for the realization of such educational process.

\section{Conclusion}

The development of modern economy in many ways relies on advances in information technologies in all areas of human activity, including education. This dictates the need for pre-professional education of schoolchildren in the field of IT based on fundamental training in informatics. Such training involves the formation of relevant competencies for future IT specialists, which requires the availability of appropriate content support, training material adjusted for modern technological and information environment with a significant activity component. Therefore, it is forming the content of IT classes with schoolchildren at an in-depth level, which allows them to master new information technologies, that is of particular relevance.

The previous methodological experience and expertise encouraged to draw the conclusion about the possibility and effectiveness of applying a fundamental approach to designing the content of a textbook for IT classes in general secondary education.

The revealed features of the fundamental approach prompted to formulate the principles of structuring a textbook for pre-professional education of schoolchildren in the IT field.

The research results contributed to designing the programme of fundamental informatics training, which is an invariant component of the pre-professional training of schoolchildren in the sphere of information technologies.

\section{References}

Berezhnova, E.V., \& Kraevskij, V.V. (2017). Osnovy uchebno-issledovatel'skoj deyatel'nosti: uchebnik [Fundamentals of educational and research activities: textbook]. Moscow: Academy.

Federal'nyy proyekt «Kadry dlya tsifrovoy ekonomiki» [Federal project "Human Resources for the Digital Economy"]. $\quad$ (2019, $\quad$ May 28). https://www.economy.gov.ru/material/directions/chelovecheskiy_kapital/kadry_dlya_cifrovoy_eko nomiki/ 
Fiziki i liriki: predprofessional'noye obrazovaniye v voprosakh i otvetakh [Physicists and Lyrics: PreProfessional Education in Questions and Answers]. (2017, February 28). Retrieved from https://mcko.ru/articles/767

Grinshkun, V.V., \& Levchenko, I.V. (2011). Osobennosti fundamentalizacii obrazovaniya na sovremennom etape ego razvitiya [Features of the fundamentalization of education at the present stage of its development]. Bulletin of People's Friendship University of Russia. Series: Informatization of Education, 1, 5-11.

Kalinin, I.A., \& Samylkina, N.N. (2019). Informatika. Uglublennyj uroven': uchebnik [Informatics. Advanced level: textbook]. Moscow: BINOM. Knowledge Laboratory.

Kontseptsiya IT-klassy Moskvy. [The concept of IT classes in Moscow]. (2019, September 1). Retrieved from https://lyc1564.mskobr.ru/it-class/koncepciya_razvitiya_it-klassov_v_shkolah_moskvy

Korzhuev, A.V., \& Sadykova, A.R. (2018). Pedagogicheskij poisk: vremya peremen [Pedagogical search: time for change]. Moscow, St. Petersburg: Nestor-History.

Kuznecova, I.V., \& Testov, V.A. (2016). Principy fundirovaniya pri izuchenii osnovnyh algebraicheskih struktur budushchimi uchitelyami matematiki [Funding principles in the study of basic algebraic structures by future mathematics teachers]. Voronezh State University Bulletin. Series: Problems of Higher Education, 1, 66-72.

Levchenko, I.V. (2009). Formirovaniye invariantnogo soderzhaniya shkol'nogo kursa informatiki kak elementa fundamental'noy metodicheskoy podgotovki uchiteley informatiki [Formation of the invariant content of the school course in informatics as an element of the fundamental methodological training of teachers of informatics]. Bulletin of People's Friendship University of Russia. Series: Informatization of Education, 3, 61-64.

Mel'nik, N.M. (2014). Fundamentalizaciya professional'nogo obrazovaniya - osnova dostizheniya vostrebovannogo innovacionnoj ekonomikoj kachestva podgotovki specialistov [Fundamentalization of vocational education is the basis for achieving the quality of training specialists demanded by the innovative economy]. Bulletin of the Samara State Technical University. Series: Psychological and pedagogical sciences, 1(21), 96-103.

Moller, F., \& Crick, T. (2018). A university-based model for supporting computer science curriculum reform. Computer in Education, 5, 415-434. https://doi.org/10.1007/s40692-018-0117-x 
Moskovchenko, A.D. (2017). Fundamental'no-tekhnologicheskaya sistemnaya klassifikaciya tekhnicheskih nauk [Fundamental technological system classification of technical sciences]. Development of technologies and content of higher vocational education as a condition for improving the quality of training of graduates (pp. 97-98). Tomsk: TSUCSR.

Natsional'naya programma «Tsifrovaya ekonomika RF» [National program "Digital Economy of the Russian Federation"]. (2020, August 11). Retrieved from https://digital.gov.ru/ru/activity/directions/858/

Pasport natsional'nogo proyekta «Obrazovaniye» [Passport of the national project "Education"]. (2018, December 24). Retrieved from http://docs.cntd.ru/document/552189837

Polyakov, K.Yu., \& Eremin, E.A. (2017). Informatika. Uglublennyj uroven': uchebnik [Informatics. Advanced level: textbook]. Moscow: BINOM. Knowledge Laboratory.

Sadovnikov, N.V. (2011). Fundamentalizaciya sovremennogo obrazovaniya [Fundamentalization of modern education]. Izvestia PGPU im. V.G. Belinsky, 24, 782-786.

Semakin, I.G., Henner, V.K., \& Shestakova, L.V. (2020). Informatika. Uglublennyj uroven': uchebnik [Informatics. Advanced level: textbook]. Moscow: BINOM. Knowledge Laboratory.

Talyzina, N.F. (2018). Pedagogicheskaya psihologiya. Praktikum: uchebnoe posobie.. [Pedagogical psychology. Practicum: tutorial]. Moscow: Yurayt.

The President signed the Decree "On national goals and strategic objectives of the development of the Russian Federation for the period up to 2024". (2018, May 7). Retrieved from http://www.kremlin.ru/acts/news/57425 